\title{
THE GLOBAL RANKING TOURNAMENT: A DIALECTIC ANALYSIS OF HIGHER EDUCATION IN SOUTH AFRICA
}

\section{R. Dlamini}

Wits School of Education

University of the Witwatersrand

Johannesburg, South Africa

e-mail: Reuben.Dlamini@wits.ac.za

\section{ABSTRACT}

The unprecedented changes in the university, to homogenizing the principle of identity in association with the dominant class (world-class universities) supports a very limited conception of higher education. The mantras of global rankings have permeated South Africa's institutions of higher education, yet the rankings' constructs are subjective, and inadequate in nature. This article uses aspects of Jurgen Habermas's 'Critical Theory of Societal Development' as its lens to account for the implications of South African universities joining the 'super-league' universities. The efforts being made to achieve a kind of iconic status are contradictory to making education a bridge to achieve equality.

Keywords: higher education, university rankings; global ranking; higher education in South Africa

\section{INTRODUCTION}

The fervor of internationalization and rapid growth of information and knowledge revolution has prompted the (top) four South African universities, which are namely; University of Cape Town, University of KwaZulu-Natal, University of Pretoria and the University of the Witwatersrand to respond to the call that universities must 'institutionalize an international dimension to prepare students for complex challenges of globalization' (Horn, Hendel and Fry 2007, 330). Internationalization is a multi-dimensional concept. Knight (2003, 3) defined internationalization as a 'process of integrating an international, intercultural, or global dimension into the purpose, functions or delivery of postsecondary education'. That means making international opportunities available to all students equitably to avoid further skewing the uneven distribution of talent and human capital.

However, with universities interpreting 'internationalization as westernization and modernization as Americanization' the challenge is how to maintain the traditional social role and service function of tertiary education in the country (Mok and Cheung 2011, 238). The danger of interpreting internationalization in a one-dimensional lens (global ranking) could result in cultural homogeneity with a Western imperial piquancy. The account provided in this 
article situates the goal of becoming a world class into several contexts explaining the implications or potential consequences of its legitimization. This article uses aspects of Jürgen Habermas's 'Critical Theory of Societal Development' as it lens to provide detailed arguments on the implications of South African universities joining the 'super-league' universities. This theory challenges the 'reified powers of domination'. It is aimed at formulating patterns of social emancipatory strategies and is oriented to the understanding of society.

The world-class label comes with obligations, and might be divorced from the realities of South African universities. The rankings are elitist in nature with established order and regulated status within the global space. Thus, universities must not react to the convenience of bourgeois culture. In the case of South Africa differentiation might be necessary, but not sufficient enough as a strategic tool. There are implications of prioritizing and legitimizing the race to join the 'super-league' universities instead of framing higher education at the societal level need. This could result in universities 'governed by values of economic rationality' instead of collective ideals in a transitioning country (Winter 2009, 123).

\section{UNPACKING INTERNATIONALIZATION AND MODERNIZATION}

In the current discourse internationalization is associated with westernization while modernization is equated to Americanization. Internationalization must not be treated as a ‘discrete phenomenon’ associated only with the Western world. The legitimization of western domination has serious implications in a young democracy. This will further reinforce western hegemony, thus promoting ideals of classism. The current discourse on global rankings, which suggests that universities must accept the systematic rationalization process of global rankings, is self-defeating and unrealistic in South Africa. The systematic rationalization has a simplistic and mechanical view in a metaphorical poeticized characteristic of a world-class university. This country ought to be developing a social theory of African universities constructed in terms of local social and economic realities. This 'social theory of African universities' will be coded with a blueprint for social improvement and humanistic intervention. The rankings are shifting the focus from sustainable cognitive development environments into a constitutive one to further reinforce the Western domination. As a country we can learn from Habermas (1987) about distorting the value of institutions of higher learning. According to Habermas (1987), there is a need to:

... protect areas of life that are functionally dependent on social integration through values, norms and consensus formation, to preserve them from falling prey to the systemic imperatives of economic and administrative subsystems growing with dynamics of their own (Habermas 1987, 372). 
Habermas assertion highlights the paradigmatic shift to systematic conformity, which is detrimental to collegiality underpinning university values in a shared governance space. The four universities mentioned above are aspiring to be world class universities with some expressing their desire to be among the top 100 world class universities. According to Wang (2013, 306) 'in a globalized world, the internationalization of education is viewed as an inevitable trend for countries across the world'. However, it is still not clear if rankings enhances the quality of teaching and learning or it is simply subscribing to commercialization and commodification of education or the idealized image of corporate efficiency. The prevailing discourse on internationalization should consider collegial practices, local realities, and what is central to higher education. The National Higher Education Plan (DoE 2001) outlines the role of higher education institutions in the new South Africa:

... to redress past inequalities and to transform the higher education system to serve a new social order, to meet pressing national needs, and to respond to new realities and opportunities (DoE White Paper 1.1 2001).

The South African space is characterized by scarce resources and competing priorities for families to be able to send their children to university. In addition, most students are entering university gates underprepared. Therefore, more resources are needed to support and enable students to be successful in tertiary education. Well-resourced families have more options on where to send their children for higher education, while those underprivileged will have difficulties integrating in the new world-class universities. The focus should be on educating for global engagement in a broadly conceived notion of academic excellence and meaningful international integration. Given that teaching, learning and research are fundamental and central to higher education, universities should be catalyst for skills and knowledge development. Professor Adam Habib, the University of the Witwatersrand Vice-Chancellor and Principal during his inaugural lecture said 'a differentiated higher education system enables responsiveness to the diverse and multiple needs of an economy and a society' (Habib 2014, 12). This article does not argue about differentiation, but that institutions of higher education must be locally relevant with broad conception in a globalized world.

In the process of differentiation it is important to create an enabling environment instead of only shifting the burden of paying for higher education to students. It is frightening to witness institutions of higher learning moving towards a more commercial approach, not considering the historical context of South Africa. Miller (2010) quoting the New Zealand Union of Students’ Association $(2009,86)$ about shifting the burden of paying for higher education to 
students which 'fails to acknowledge and recognize the social, cultural and economic advantages that a society gains when a large majority of its citizens have open and free access to public tertiary education'. With universities expected to play a significant role in the transformation of the population socio-economic status, there is a need to avoid any structures that compromise the 'Rainbow Nation' constitutional vision. According to Professor Habib:

The South African Constitution, demands that its public institutions simultaneously address the historical disparities bequeathed by Apartheid and build a collective national identity. The second, written in the manifesto and architecture of any great university, is the imperative to be both nationally responsive and cosmopolitan at the same time (Habib 2014, 2).

The enormous challenge that institutions of higher learning need to address is how to make tertiary education more than entering the university gates. The enrolment numbers are looking healthy, but with low student retention and graduation rates, and the increasing cost of higher education these fundamental questions need to be asked:

- Why is it that almost 55 per cent of students who enter the university will not complete their studies?

- Why is it that fewer than 25 per cent of students will complete their degrees within the minimum allocated time?

- Does entering the global 100 top universities or becoming a world-class university translating to high student retention and graduation rates?

- Is international benchmarking translating to better teaching and learning experiences for students?

- Is it enough to aim to become a world-class university or South Africa should make the university system a world-class?

These questions raise contesting issues that need to be confronted as a matter of urgency and addressed to avoid the continuation of historical disparities. The implications of low graduation and retention rates add to the complexities suffered by the National Student Financial Aid Scheme (NSFAS). NSFAS is the South African government student financial aid scheme in the form of loans and bursaries. With low graduation rates the scheme has become an unsustainable model, placing a lot of pressure on the scheme. This work is not advocating for a limited view of the current complex problem in higher education as it will not reduce inequality. However, this article does advocate for new innovative ways to fund higher education with appropriate access model for all qualifying students especially now that NSFAS funding has come to a 
'screeching halt'. However, this is a two way street because students have a role to play in freeing the limited resources, by graduating on time.

If students continue not to graduate on time financial resources are put under a lot of pressure. Therefore, new students have to depend on student loans and those not graduating on time run the risk of accumulating high debt. In the event the students continue to accumulate high debt the country is running a risk of students from underprivileged backgrounds avoiding higher education. Fear of accumulating high debt is a greater deterrent for students coming from historically marginalized groups. Then the question is 'Should tuition fees be capped?' This work is not in any way advocating for cap on fees 'creating oligopolistic behavior at best, monopsonistic at worst' (Miller 2010, 94). Increasing class sizes and teaching loads is not a solution given the low graduation and retention rates among historically disadvantaged groups. Evidently current student success still differentiated along color lines despite the ever expanding diversified student profiles on university campuses.

Institutions of higher education need to adopt a clear vision on how to effect social change and enact policies to ensure that the desired change is realized. Yes, universities are not obligated to accommodate students' circumstances, but they do have a moral duty to educate, skill students, and make sure that they graduate on time. Universities need to put in place academic support units and develop inclusive and innovative approaches to pedagogy in order to meet the unique needs of historically marginalized groups. There must be a participatory strategy marrying equity and efficiency between universities and government to look at how best to finance higher education to alleviate financial burden on the students. The notion of entering the super league table or becoming a world class university needs to be tested against the country's realities recognizing that higher education is a 'public good' (Mohamedbhai 2011, 3). This article recognize higher education as a public good to improve human capital through education boosting the economic development and contribute to social and personal transformations.

Consequently, the stance this article takes is that universities ought to consider their context and citizens' historical background as the foundation for making the sought-after improvements. According to Ojo and Booth $(2009,309)$ for a university to successfully gain entry into the category of world class universities and strengthen their international profiles, it has to 'reconsider its mission, tasks and responsibilities, as well as develop innovative strategies to improve their relevance and function'. Higher education is a major engine for economic development by contributing to capacity development to sustain future social and economic growth. This is a call for South African universities to fundamentally restructure their social and service constructs, which are central to the well-being of contemporary society. Therefore, 
the 'public good of value' to society should dominate any discourse as South Africa deals constructively with issues of uneven distribution of human capital and unsustainable models of funding tertiary institutions. If gaining world-class and prestige is the ideal solution to the uneven distribution of human capital and equality, then joining the 'super-league' is the way to go.

\section{A WORLD-CLASS UNIVERSITY}

According to Salmi $(2009,4)$ the world-class status is 'conferred by the outside world on the basis of international recognition'. He continues to explain that the declaration of attaining a world class university is not something achieved through self-declaration (Salmi 2009). Philip Altbach, Director of the Center for International Higher Education at Boston College said 'everyone wants one, no one knows what it is, and no one knows how to get one' (Altbach 2004). The international community conferred this status based on international recognition via academic programs, research output and technology transfer (NCPPHE 2008; Altbach 2012). There is no doubt that the shift stems from external influences and the adoption of the corporate model in institutions of higher learning. According to Saravanamuthu and Tinker $(2002,545)$ 'reconfiguration of the University has been associated with managerialism, corporatization, marketization, customerization, modernization, professionalization, and last but not least, rationalization'. Again, these imperatives 'are driven by the (unproven) belief that economic rationalism must prevail in the University to successfully take advantage of the challenges posed by globalization, advances in information technology as well as the concentration of capital in mega-corporations' (Saravanamuthu and Tinker 2002, 545). The effect of having a growing influence in higher education by corporations makes institutions look like a subsidiary of a business enterprise.

The corporate model system, by nature is entrepreneurial and market driven, therefore the model allows little room for 'shared governance' which is fundamental to the operation of higher education institutions. Intrinsic to the corporate model is the presence of corporations on campus and corporate executives sitting on university boards or council that have accelerated the imminent takeover of institutions of higher learning by the private sector, thus also bringing business practices and culture. In the process creating 'hidden constructs'. Hidden constructs are defined as 'discourse that takes place off-stage beyond direct observation by power holders'. In the current climate of higher education, it is understood that universities are facing financial constraints, but the corporatization of higher education does not dismantle barriers to education for all. There is no clear research-based evidence to prove that corporatization add value to inclusive education except for reputational value. 
Reputational value is in line with the world-class, which distorts Newman's 'Idea of a university' (Singh 2002, 681). Furthermore, the goal of becoming a world-class is problematic as it is construed as an indicator of success. The world-class status has relied on perceived reputation, therefore very subjective and relative as it is 'adjudicated on the basis of comparison with other universities' (Xavier and Alsagoff 2013, 227). Xavier and Alsagoff (2013) alluded to the fact that they are here to stay despite 'their short-comings, evident biases and flaws' (Rauhvargers 2011, 7). The reputational value is then used as an 'organizational measure in accreditation by professional body and international rankings' (McDonald 2013, 652). Therefore, are we internationalizing for cooperation or corporatization or for social advancement? Thus, South African universities must not flatten out the realities of the country as they form productive partnership with prestigious and world-class universities.

Student access, achievements, retention, and progression should remain central to South African universities. Therefore, education should not be used to divide and polarize our societies, widening the gap between those marginalized groups and those who benefitted in the past injustices. South African Public Protector, Thuli Madonsela addressing the University of Stellenbosch community stated that 'South Africa is one of the most unequal societies in the world.' Given that South Africa suffers from such disparities, then in the interest of justice and access, education should give real meaning to students' socioeconomic development and upward mobility. The concerns are the failure of institutions of higher learning to address social inequalities, massification of higher education and students' continuation of funding higher education at all levels. Professor Visser, Deputy Vice-Chancellor: Research at UCT in his remarks said that 'none of the rankings give a perfect view of a university'. Thus, as a country we need quality education experience that is aligned with societal and individual student needs.

\section{RATIONALE FOR INCREASING INTERNATIONAL PROFILE}

Internationalization has reshaped all aspects of higher education around identity and reputation. In the past universities were conceptualized around values, collegial practices, and educational standards. In a bid to be counted amongst the world class universities the top four South African institutions of higher learning developed strategic plans to strengthen their international profiles. These strategic plans are reflected in Table 1 and provide clear evidence that the universities are determined to achieve the kind of iconic status which is referred to by students and their respective families to determine their university of choice (Altbach 2012). According to Altbach $(2012,27)$ it is about what '... universities have to offer in terms of the prestige, value and price of their degrees'. It is noteworthy that it is unclear whether the universities in South Africa are responding to the shifting $21^{\text {st }}$ century academic landscape or are developing 
educational institutions that 'instill core human values and strengthening social structures to ensure that future generations experience lives of justice, equity, and fulfilment' (NCPPHE $2008,1)$. Or are the universities shifting to view higher education through service lens?

In the research conducted by Ojo and Booth (2009) students acknowledge that the internationalization of Wits to be among the global 100 was critical. In pursuit of the global 100 goal Wits and other South African universities need to meet some of the general internationalization standards, such as open access through institutional networks and collaboration. Included in the top 100 universities worldwide is the Association of American Universities (AAU). AAU is made up of the world leading research universities and membership is by invitation only. Membership is based on breadth and quality of research, research spending, faculty in National Academies, faculty awards and publications citations. Therefore, in order for South African universities to pursue the world class status successfully, they must have access to similar resources the AAU institutions own. However, that in itself calls for shifts in prioritization requiring that significant resources be devoted to image management rather than the core mission of the university: teaching, learning and research. It is noteworthy to acknowledge that the fervor of internationalization has given a rise to academic identity schisms.

Central to the identified identity schism is the notion of values fit and organisational situations in which academics and managers' ideological beliefs and values may not overlap in respect to the roles and obligations of academics and the primary purpose of the institution (Winter 2009, 122).

In lieu of identity schism there is a rise of institutional rankings, yet the 'Idea of a university as first and foremost a place of learning, a community of educated persons "devoted to the pursuit of intellectual truth, as an end in itself, and, as such, fulfilling a central and ethical role for society at large" act as an important glue that holds both the academic and institution together' (Coady 2000, 6). The issue of rankings adds to complex and multifaceted institutions of higher learning contriving themselves in a market-oriented space. Instead, the important transformation for universities is their alignment with societal needs and contributing to knowledge production in formed by local context. Internationalization of higher education should not make us blind, but do consider historical and cultural dimensions, then put supporting structures in place.

The $21^{\text {st }}$ century University is learner-centered institution. Segall and Freedman $(2007,5)$ asserted that higher education is 'facing the demands of a world with new quickly changing student demographics, an increasingly flat global environment, and tighter funding and accountability constraints'. Therefore, for South African institutions to compete with their 
global counterparts, need to change with the times in as far as their strategic response to globalization is concerned (Dlamini 2011). In a 'market-driven, student-centered and businesslike management and accountability strategies' the suggestion is that universities adopt a complex socio-economic and cultural framework system as their lens. This can be done under the 'umbrella of morphogenesis' (Kotta, Case and Luckett 2014, 516). According Kotta, Case and Luckett $(2014,516)$ 'Archer's morphogenetic sequence starts with the structural and cultural conditioning of a context, which constrains or enables interaction, which then leads to social or cultural elaboration or stasis'. The challenge in South Africa is that social inequalities,

... were embedded and reflected in all spheres of social life, as a product of the systemic exclusion of blacks and women under colonialism and apartheid. The higher education system was no exception. Social, political and economic discrimination and inequalities of a class, race, gender, institutional and spatial nature profoundly shaped, and continue to shape, South African higher education (Badat 2010, 4).

Therefore, universities need to reconstruct their identities and institutionalize a new social order. See Table 1 for four South African Universities Strategic Goals. The overarching and common goal among the top four public universities in South Africa is to strengthen their international profile and internationalization of their students' experience is evident in Table 1. Bourdieu (1993) makes known that higher education is uneven, hierarchical, shifting, and contested. In his assertion Pierre Bourdieu (1993) said institutions of higher learning are ‘engaged in “position-taking” strategies' (Bourdieu 1993, 35). This is evident among South African universities which are working on strengthening their international profiles, while others explicitly state that they want to be in top 100 universities in the world.

Table 1: Top four South African universities strategic goals

\begin{tabular}{|c|c|}
\hline $\begin{array}{l}\text { Top } 4 \text { public universities in } \\
\text { South Africa }\end{array}$ & Universities strategic goals \\
\hline $\begin{array}{l}\text { University of Cape Town } \\
\text { Strategic Plan 2010-2014 }\end{array}$ & $\begin{array}{l}\text { - } \quad \text { Enhance UCT's position as an Afro-politan university } \\
\text { - } \quad \text { Strengthen UCT's international research profile } \\
\text { - } \quad \text { Enhance graduate attributes } \\
\text { - } \quad \text { Internationalize the student experience } \\
\text { - } \quad \text { Ensure staff development } \\
\text { - } \quad \text { Contribute to the resolution of problems which are of global significance }\end{array}$ \\
\hline $\begin{array}{l}\text { University of Kwazulu-Natal } \\
\text { Strategic Plan 2007-2016 }\end{array}$ & $\begin{array}{l}\text { - To promote African-Led globalization by entering the global knowledge } \\
\text { system } \\
\text { - } \quad \text { Contribute to knowledge prosperity and sustainability of KwaZulu-Natal, } \\
\text { and nation-building } \\
\text { - } \quad \text { Pre-eminent producer of new knowledge that is both local as well as } \\
\text { global in context } \\
\text { - } \quad \text { Excellence in teaching and learning } \\
\text { - Institution of choice for students } \\
\text { - Institution of choice for staff }\end{array}$ \\
\hline University of Pretoria & - To be a leading research-intensive university \\
\hline
\end{tabular}




\begin{tabular}{|c|c|}
\hline Strategic Plan 2025 & $\begin{array}{l}\text { - To strengthen the university's international profile } \\
\text { - To strengthen the university's impact on economic and social } \\
\text { development } \\
\text { - To pursue excellence in teaching and learning } \\
\text { - To increase access, throughput and diversity of students }\end{array}$ \\
\hline $\begin{array}{l}\text { University of the } \\
\text { Witwatersrand }\end{array}$ & $\begin{array}{l}\text { - } \quad \text { To increase the intake and throughput of quality graduates } \\
\text { - } \quad \text { To increase the percentage of postgraduate and research students } \\
\text { - } \quad \text { To be among the world-100 universities } \\
\text { - } \quad \text { To attract, inspire and retain quality academic and support stuff }\end{array}$ \\
\hline
\end{tabular}

\section{THE REALITIES OF SOUTH AFRICAN UNIVERSITIES}

Issues around ranking have drawn the international community's attention when deciding on where to send their children for higher education. In fact, the ranking of South African universities has become their present day reality, thus motivating them to work relentlessly to break into the top 100 universities in the world. Also, their aim is to become highly competitive in teaching and research as well as offer relevant academic programs. After all, the economic and social development of any country is dependent on highly skilled citizens and the quality of their human capital. This brings to fore a concern that permeates the skills and development literature in South Africa which cites the condition of a severe shortage of skills and universities are expected to significantly make an impact by addressing this challenge.

It is important that our universities portray and position themselves as ideal spaces for intellectual advancement and common ground for shared civil discourse. As Universities develop students' capacity to compete in the global space, there is no need to succumb to pressures of participating in the global rankings. Instead, South African universities need to craft their own identity within the global space and contextualize their existence. Bearing the local context in mind, the argument regarding attracting sponsors is flawed, because universities in South Africa are still largely funded by the government and the escalating students' fees. Similarly, in cases whereby international organizations fund local projects, they still rely on the government of South Africa for continuity or sustainability of the projects. However, that does not mean universities cannot feature in the global space by contextualizing the case of South African universities given the historical past. As a country we must learn from the words of Dr Badat, the former Vice Chancellor of Rhodes University in his resignation statement,

I have counselled against an obsession with global rankings and on the need to remain focused on the core idea, meaning and purposes of what it means to be a university - not just in abstract, but under the real conditions of a developing and transforming the country and changing continent and world.

Focusing on rankings has resulted in intensifying challenges in our institutions of higher learning because we then began to adopt corporate practices. Intrinsic to the corporate model is 
the presence of corporations on campus as service providers and corporate executives and political heavyweights sitting on councils that have accelerated the imminent takeover of institutions of higher learning by the private sector whilst concurrently bringing business practices and culture. Even though universities' funding lie on life support and donors' pockets deflate, the growing influence of corporations in the day-to-day operation of universities results in the distortion of shared governance. As a possible solution, universities have to support the country's social projects and stop acting like they have fiduciary obligation to the corporate world for their survival. This is because the corporate culture suffers from dominative principles, which promote hegemonic tendencies. Marxist Philosopher Antonio Gramsci defined hegemony as the dominance of one social class over other social classes or the dominance of one political unit over other units (Borg et al. 2002). The observation in the New York Times in 1998 still holds today:

... The danger today is that the administrations that now set policy at most universities are increasingly tempted to act as if they are running a business - letting profit motives drive educational policy. In such a climate, revenue-generating programs and inexpensive part-time professors are winning out over a committed faculty, good libraries, and small classes (Shapiro 1998).

The administration should use their power to emancipate students; faculty and staff, instead of making the subordinate internalize their ideals that subscribe to hierarchical domination. There is a great need to keep faculty, staff and students interested and motivated, thus innovative curriculum and inclusive governance or leadership method is crucial. There should be a balance of power and governance to fulfill the mission of universities and provide students with lifechanging educational experience instead of partnering corporations to deliver just-in-time skills without the participation of faculty members. As we continue to debate these issues we must all bear in mind that there is no better gift a country can offer to its citizens that can be compared to 'education for all' (EFA). All children regardless of their unfortunate socioeconomic backgrounds should be given an opportunity. Traditionally black universities such as the University of Fort Hare should be transformed and all other universities should implement policies that will empower all students, lower tuition fees and provide the necessary support. Dominative principles, which promote hegemonic tendencies, should be dismantled in order to achieve maximum value of education and meet the core needs of our country.

Simply attracting students from historically disadvantaged backgrounds onto campuses without the necessary support apparatus to unlock their potential and enable them to become part of the institutional culture is inadequate. Such acts tend to reinforce the past injustices as 
the students will have to drop out and sometimes take longer to graduate and in the process continue to accumulate massive debts. Therefore, the suggestion is for universities to view higher education through a service lens to transform and improve student educational experience and their professional development.

\section{UNIVERSITY RANKING}

For universities to increase their global standing, they need to develop the capacity to compete through adaptation and creation of advanced knowledge. There is no doubt concerning the importance of the relevance of South African universities in the global space but it should never oversimplify their complex post-apartheid reality. The current challenges for most universities are: 'low student retention and graduation rates, the increasing cost of higher education, and concerns that graduates don't possess the skills required to compete successfully in today's interconnected, global marketplace' (Bitner, Ostrom and Burkhard 2012, 38). There is no clear evidence in the literature that participating in the ranking tournament addresses the challenges chronicled above. The global ranking tournament seems to focus more on prestige rather than transforming the student experience and skills development.

Instead our universities are preparing to enter the new league called the Super-League of global universities. These universities in the 'super-league' are battling for intellectual talent and academic prestige. Perhaps South African universities instead of participating in the race to join the 'super-league' could consider the Carnegie Classification of Institutions of Higher Education given the country's historical context. The Carnegie Classification of Institutions of Higher Education serves as a 'framework for recognizing and describing institutional diversity in the USA', not as a ranking mechanism (Altbach 2012, 27). Participating in the ranking tournament is not meaningful because the rankings lack clear standard measures of the core mission of the university except in terms of research productivity (publications, research funding, and Nobel laureates).

At least the Carnegie Classifications group 'institutions into meaningful, analytically manageable categories in order to allow researchers to make reasonable comparisons among similar institutions' (Carnegie Foundation 2011). All the ranking professional association seems to ignore the measure of teaching quality and social services yet those are the core components of the mission of an institution of higher learning (Altbach 2012). The view of this work is that universities exist to serve students and society at large. Bitner, Ostrom and Burkhard $(2012,40)$ propose viewing higher education through a service lens which '.. puts the consumer at the center of improvement and innovation initiatives and considers the consumer's experience to be a foundation for analyzing and making enhancements'. In the 
ranking tournament the focus is on prestige than transforming the student experience. It is evident that research dominates the rankings. Below are some of the professional associations conducting university rankings and the methodologies used:

- The Times Higher Education Supplement (THES) uses the following measures: 'international reputation, combining subjective inputs such as peer reviews and employer recruiting surveys and quantitative data, including the numbers of international students and faculty, and the influence of the faculty, as represented by research citations' (Salmi 2009, 3).

- The Shanghai's Jiao Tong University (SJTU) uses the following measures 'objective indicators, such as the academic and research performance of faculty, alumni, and staff. The measures evaluated include publications, citations, and exclusive international awards, such as Nobel prizes and Fields medals’ (Salmi 2009, 3).

- Institute for Higher Education Policy (IHEP) - uses existing data or original survey data, then the type and quantity of variables selected gathered information and lastly they use standardized and weighted from selected variables and then perform statistical calculations then comparisons takes place resulting in the rankings (IHEP 2007).

- $\quad$ Academic Ranking of World Universities (ARWU) considers every 'university that has any Nobel Laureates, Fields Medallists, Highly Cited Researchers, or papers published in Nature or Science. Also use universities with significant amount of papers indexed by Science Citation Index-Expanded (SCIE) and Social Science Citation Index (SSCI)' (http://www.shanghairanking.com/ARWU-Methodology-2012.html)

- The Times of London is the newest university ranking group. The Times uses the universities core mission: teaching (learning environment), research (volume, income and reputation), knowledge transfer (innovation) and international outlook (staff, students and research). The methodology is broken down as follows with its weighting system on the overall ranking score: teaching (worth 30 per cent), research (worth 30 per cent), citations (worth 30 per cent), industry income (worth 2.5 per cent) and international outlook (worth 7.5 per cent) (http://www.graddiv.ucsb.edu/facts-figures/times-higher-education).

Based on the ranking criteria provided by the professional associations conducting university rankings, South African universities need to use those criteria as their framework in developing their strategies for the future. The existing professional associations conducting university rankings lack the actual measure of teaching 'quality' which is one of the main functions of a 
university. Salmi (2009) provides a framework summary in Figure 1 of those aspiring to be world class universities.

It is evident that being a world class university is more than just a declaration of certain principles. There are compulsory changes that need to be realized like being research intensive university. Figures 2 to 6 show countries with universities in the Top 100 in the World.

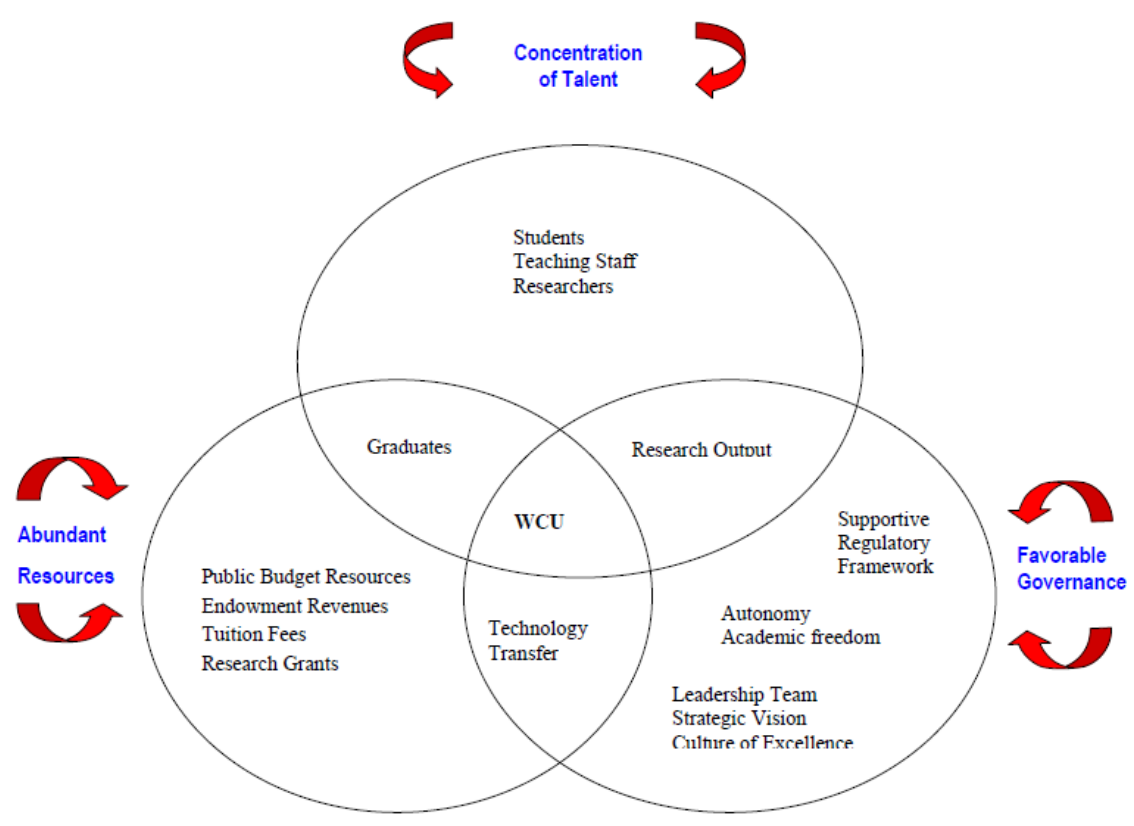

Figure 1: Characteristics of world class universities (Salmi 2009, 8) 


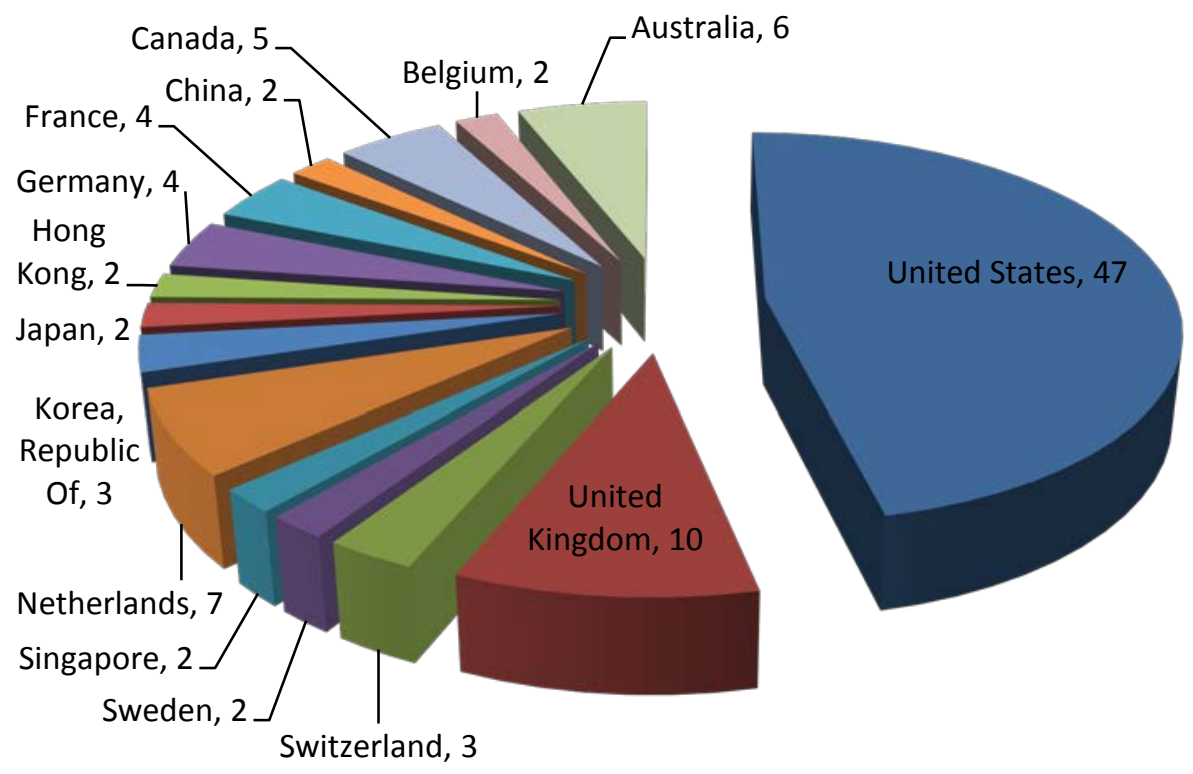

Figure 2: THE Top $100-2012$

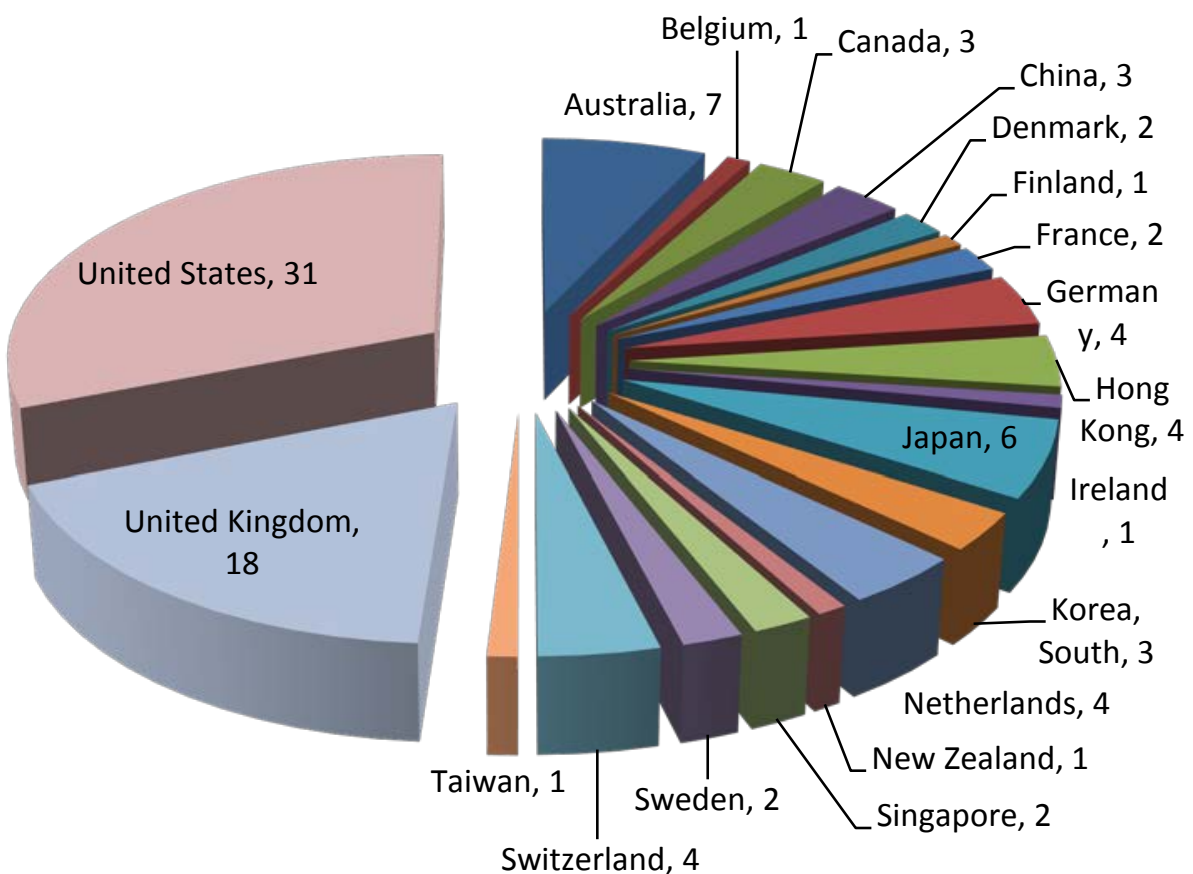

Figure 3: QS Top 100 - 2012 


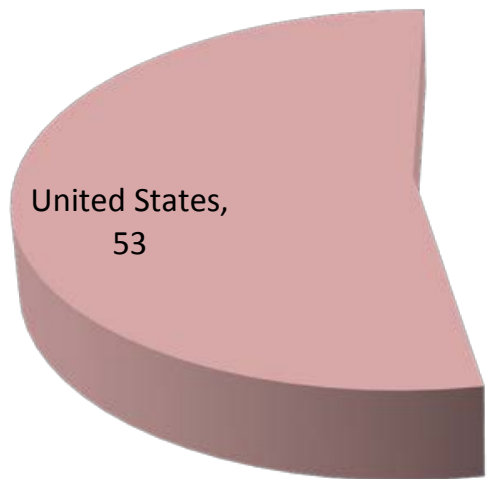

Figure 4: ARWU Top 100 - 2012
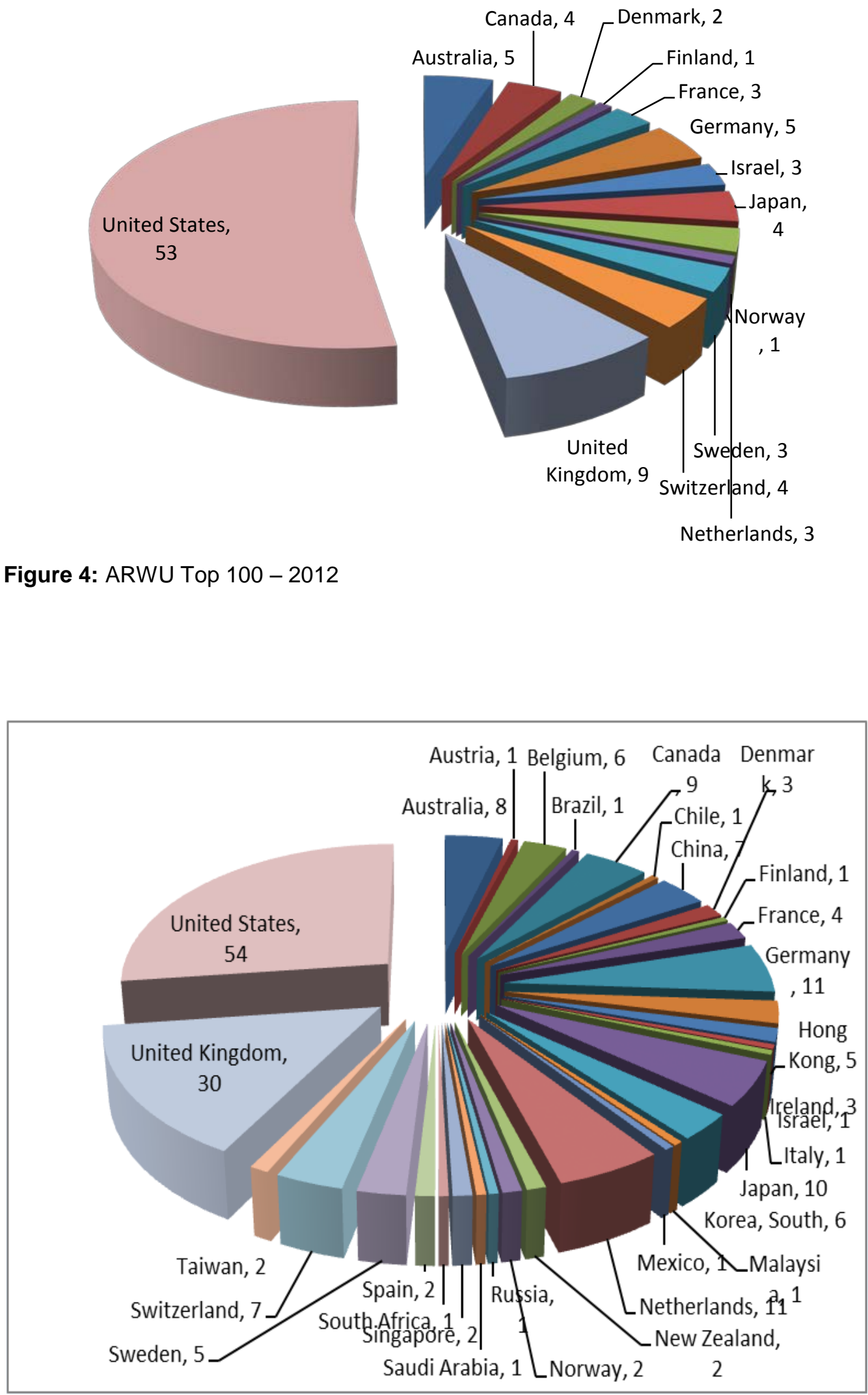

Figure 5: QS Top 200 - 2012 


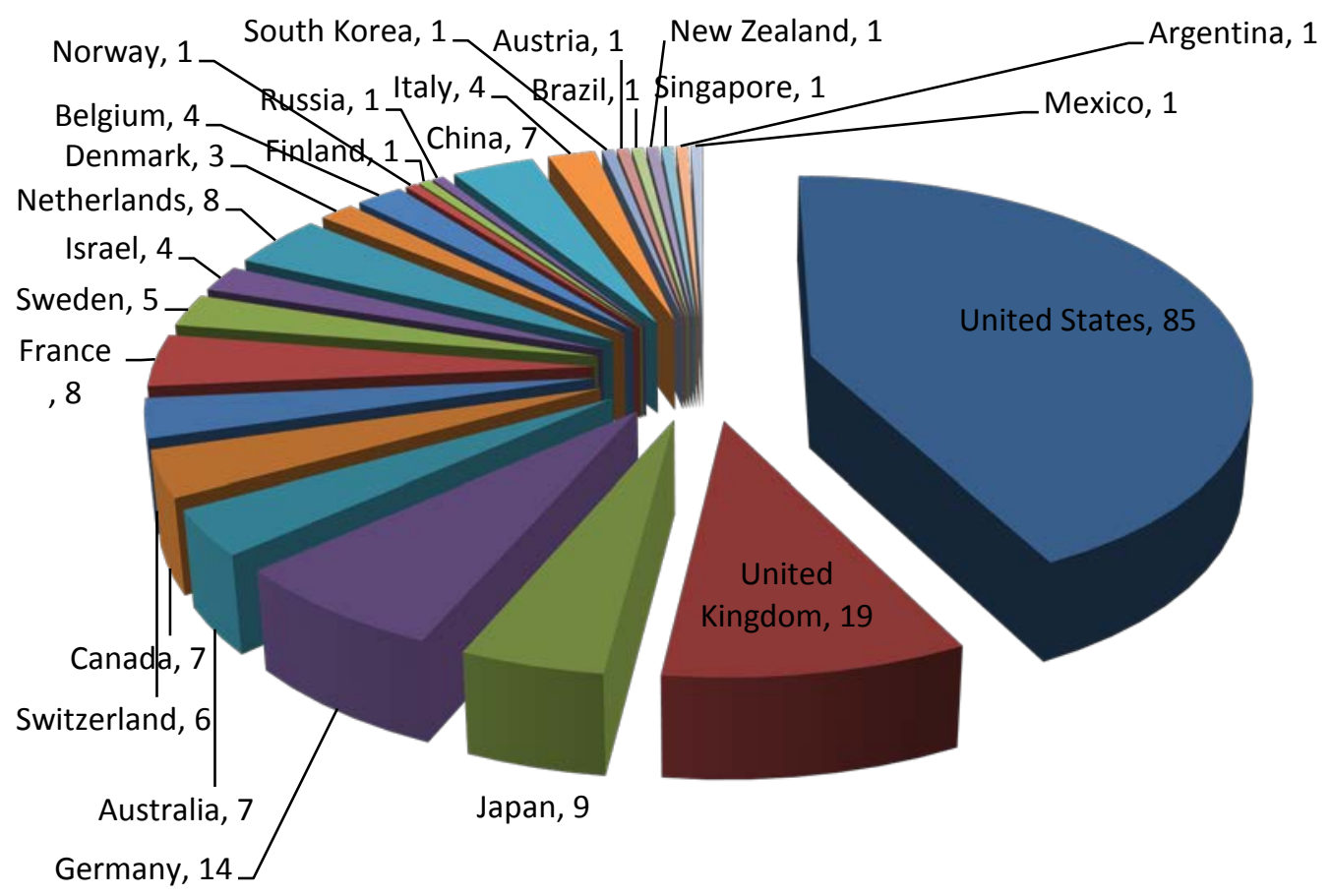

Figure 6: ARWU Top 200-201

\section{SUMMARY AND CONCLUSION}

In Figures 2-6 African countries do not feature, thus this article contends that it should not be about gaining the prestigious status and well sought after iconic status, but rather personal development, social transformation and tolerance. Universities should consider the students demographic and socio-economic standing as they work on joining the Super-League of global universities and strengthening their international profiles. It rings true that education is a fundamental right enshrined in the Constitution of the Republic of South Africa and it is not a privilege. The current discourse on global rankings, which suggests that universities must accept the notion of global ranking, is self-defeating and unrealistic given our country's historical context of social inequalities. Continuing to allow the neoliberal ideologies driven by the ‘supranational organization' such as the World Bank, and the International Monetary Fund (IMF), South African institutions will continue to conform to western values 'further reinforce the Americans-dominated hegemony’ (Mok and Cheung 2011, 238). A multidimensional approach need to be adopted instead of playing by the rules favoring the Western systematic approach.

In addition, to counter the effects of neoliberalism, universities in South Africa need to return to their mission to contribute to sustainable development and re-ignite wider intellectual conversations, whereby the under-represented groups are not quite all marginalized. Post-1994, 
South Africa has emphasized education for all, therefore institutionalizing a new social order is necessary. If the new order can be achieved by our institutions becoming world-class universities then that is the way to go. Unfortunately, being a world-class university is not achieved through self-declaration. A lot of resources need to be made available in order for transformation and education for all to happen. Professor Toni Morrison’s (2001) view:

If the university do not take seriously and rigorously its role as guardian of wider civic freedoms, as interrogator of more and more complex ethical problems, as servant and preserver of deeper democratic practices, then some other regime or ménage of regimes will do it for us, in spite of us, and without us.

In South Africa being a world-class must translate to skills development to meet the challenges of industrialization. In this light, the country must have access to local talent which is seen as strategic approach to alleviating social injustices and economic growth. The fact that there is no clear evidence that participating in the ranking tournament addresses any of the pertinent challenges that students are faced with such as student retention, graduation rates, skills development and cost of attending universities. In the United States of America (USA) less than 60 percent of students who enter four-year institutions earn a degree within six years, and we are not far from that picture or even better in South Africa (SA) (Bitner, Ostrom and Burkhard 2012). Universities need to be addressing the financial and time burden incurred by students and their families. In addition to these, there are also worries about higher education that is beneficial to society at large through the development of skills that are required to compete successfully in today's interconnected global space. These issues require new thinking and innovative approaches to higher education, which will inevitably contribute positively towards achieving the much sort after recognition and status of being world-class universities.

Universities in South Africa must create their own 'hybridized' brands in the global space. This 'hybridized' brands informed by local realities and conditions in order to continue producing local knowledge in the international community. The qualifications are already recognized in the international community; therefore, the aim should be to continue participating in knowledge production within a global space instead of adopting and implementing elite university concepts. The country needs multidimensional institutions to become actors in the socio-economic development of individuals and communities to redress existing inequalities which are products of policies, structures and practices. In the spirit of an 'Ideal University' the Carnegie Classifications is more relevant and allow universities to make reasonable comparisons among similar institutions. Therefore, in the process contributes to meaningful higher education systems, rather than few elitist world-class universities. 


\section{REFERENCES}

Altbach, P. G. 2004. Globalization and the university: Myths and realities in an unequal world. In The NEA 2005 almanac of higher education, ed. National Education Association, 63-74. Washington, DC: National Education Association.

Altbach, P. G. 2012. The globalization of college and university rankings. Change: The Magazine of Higher Learning 44(1): 26-31.

Badat, S. 2010. The challenges of transformation in higher education and training institutions in South Africa. Development Bank of Southern Africa.

Bitner, M., A. L. Ostrom and K. A. Burkhard. 2012. Service blueprinting: Transforming the student experience. Educause Review November/December.

Borg, C., J. A. Buttigieg and P. Mayo. 2002. Introduction. Gramsci and education: A holistic approach. In Gramsci and education, ed. C. Borg, J. A. Buttigieg and P. Mayo, 1-23. Lanham, MD: Rowman \& Littlefield.

Bourdieu, P. 1993. The field of cultural production. Cambridge: Polity Press.

Carnegie Foundation for the Advancement of Teaching. 2011. A classification of institutions of higher education. (2010 Edition). Princeton. http://classifications.carnegiefoundation.org/ (accessed 22 March 2011).

Coady, T. 2000. Universities and the ideals of inquiry. In Why universities matter: A conversation about values, means and directions, ed. T. Coady, 3-25. Sydney: Allen \& Unwin.

Department of Education. 2001. The National Plan for Higher Education. http://www.polity.org.za/ $\mathrm{html} /$ govdocs/misc/higheredu

Dlamini, R. S. 2011. The evolution of Information Technology Executive position in higher education: The strategic and adaptive Chief Information Officer in higher education. Doctoral dissertation, Ohio University.

DoE, see Department of Education.

Habib, A. 2014. Transcending the past and reimagining the future of the South African university. Inaugural Lecture. http://www.wits.ac.za/files/5b4ds_167906001417166876.pdf (accessed 1 December 2014).

Habermas, J. 1987. The theory of communicative action. (T. McCarthy, Trans. Vol. 2). Cambridge: Polity Press.

Horn, A. S., D. D. Hendel and F. W. Fry. 2007. Ranking the international dimension of top research universities in the United States. Journal of Studies in International Education 11(3-4): 330-358.

IHEP, see Institute for Higher Education Policy.

Institute for Higher Education Policy. 2007. College and university ranking systems: Global perspectives and American challenges. Washington DC.

Knight, J. 2003. Updating the definition of internationalization. International Higher Education 33: 23.

Kotta, L., J. Case and K. Luckett. 2014. Contradictions in the situational logic of the university: Implications for student success. South African Journal of Higher Education 28(2): 514-532.

McDonald, G. 2013. Does size matter? The impact of student-staff ratios. Journal of Higher Education Policy and Management 35(6): 652-667.

Miller, B. 2010. The price of higher education: How rational is British tuition fee policy? Journal of Higher Education Policy and Management 32(1): 85-95.

Mohamedbhai, G. 2011. Higher education in Africa: Facing the challenges in the $21^{\text {st }}$ century. International Higher Education 63(Fall).

Mok, K. H. and A. B. Cheung. 2011. Global aspirations and strategising for world-class status: New 
form of politics in higher education governance in Hong Kong. Journal of Higher Education Policy and Management 33(3): 231-251.

Morrison, T. 2001. How can values be taught in this university. Michigan Quarterly Review: 278.

National Centre for Public Policy and Higher Education. 2008. Measuring up 2008: The National Report Card on Higher Education. The National Centre for Public Policy and Higher Education, San Jose.

NCPPHE, see National Centre for Public Policy and Higher Education.

New Zealand Union of Students’ Associations. 2009. Campaigns - Fees. http://www.students.org.nz/ index.php?page $=$ fees (accessed 17 May 2009).

Ojo, E. and S. Booth. 2009. Internationalisation of higher education in a South African university: A phenomenographic study of students' conceptions. Education as Change 13(2): 309-323.

Rauhvargers, A. 2011. Global university rankings and their impac. Leadership for World Class Universities Challenges for Developing Countries June. European University Association Report on Rankings 2011.

Salmi, J. 2009. The challenge of establishing world-class universities. Washington, D.C.: World Bank.

Saravanamuthu, K. and T. Tinker. 2002. The university in the new corporate world. Critical Perspectives on Accounting 13(5): 545-554.

Segall, P. and G. Freedman. 2007. Building the 21st century campus. White Paper, Blackboard Leadership Survey, May.

Shapiro, J. 1998. Beyond the culture wars. https://www.nytimes.com/books/98/01/04/reviews/ 980104.04shapirot.html

Singh, G. 2002. Educational consumers or educational partners: A critical theory analysis. Critical Perspectives on Accounting 13(5): 681-700.

Wang, L. 2013. Going global: The changing strategy of internationalisation of education in China. Journal of Higher Education Policy and Management 35: 305-315.

Winter, R. 2009. Academic manager or managed academic? Academic identity schisms in higher education. Journal of Higher Education Policy and Management 31(2): 121-131.

Xavier, C. A. and L. Alsagoff. 2013. Constructing 'world-class' as 'global': A case study of the National University of Singapore. Educational Research for Policy and Practice 12(3): 225-238. 